\title{
Effect of frozen storage and hydrocolloids on structural and rheological properties of frozen roti dough supplemented with rice bran
}

\author{
Khanittha MUADIAD ${ }^{1}$, Piyarat SIRIVONGPAISAL ${ }^{2 *}$
}

\begin{abstract}
This study investigated the effect of addition of hydrocolloids (hydroxypropyl methylcellulose: HPMC, and xanthan) and frozen storage on the structure and rheological properties of frozen roti dough supplemented with rice bran. The roti dough was frozen by air blast freezing and stored at $-18^{\circ} \mathrm{C}$ for 84 days. Changes in the protein structure of the frozen roti dough with HPMC produced greater changes in the gluten network and random coil conformations than that of the xanthan supplemented dough during frozen storage. The resistance to extension and the elastic modulus of the frozen roti dough with HPMC tended to decrease while the extensibility slightly increased with a longer frozen storage time. However, these parameters did not change in the frozen roti dough with xanthan. The freezable water in the frozen roti dough with HPMC and xanthan significantly increased $(\mathrm{p}<0.05)$ with increasing frozen storage time from 0 to 84 days.
\end{abstract}

Keywords: frozen dough; rheological properties; rice bran; frozen storage.

Practical Application: Reduction the damage of gluten network of frozen roti dough with rice bran during storage using hydrocolloid.

\section{Introduction}

Roti is flat unleavened bread prepared from flour, water, salt, sugar and fat. About $85-90 \%$ of the consumption of wheat is in the form of roti in its various forms, such as chapatti, tandoori roti, nan, paratha and poori (Guarda et al., 2004). However, it is well known that roti has a short shelf life so has to be eaten immediately after being cooked since numerous undesirable physicochemical changes, termed staling, occur in a relatively short time after it is prepared. In view of this problem, freezing has been used and widely applied. However, freezing and frozen storage may have deleterious effects on the rheological properties and structural behavior of roti dough and finished products. The use of hydrocolloids to minimize the damage to the gluten network caused by freezing and frozen storage has become a common practice in bakery products. The addition of hydrocolloids to frozen dough tends to lower fusion enthalpy, causing a decrease in the freezable water content due to the binding of free water, and also helps to control moisture migration. This results in a reduction of ice crystal formation and a consequent reduction of freeze damage to the gluten network (Sharadanant \& Khan, 2003).

There have been many reports published of research on the influence of hydrocolloids on frozen dough (Barcenas et al., 2004; Mandala \& Sotirakoglou, 2005; Mandala et al., 2008; Matuda et al., 2008; Meziani et al., 2011). However, there have been no empirical research has been published relating to frozen roti dough supplemented with rice bran. The aim of the research work reported herein, therefore, was to evaluate the effects of the incorporation of hydrocolloids and frozen storage on the rheological and structural properties of frozen roti dough supplemented with rice bran.

\section{Materials and methods}

\subsection{Materials}

Defatted rice bran from Thai Edible Oil Co., Ltd., Bangkok Thailand, was dried in a hot air oven at $60^{\circ} \mathrm{C}$ until the moisture content was less than $5 \%$. The other raw materials used were wheat flour, margarine, milk, egg, salt and sugar, which were obtained from a local market in Songkhla, Thailand. The hydrocolloids used in this study were HPMC (Methocel K4M, Dow Chemical, Switzerland) and xanthan (Danisco Cultor, Chile).

\subsection{Dough preparation}

Roti dough was prepared using two different doughs. The first dough $(80 \mathrm{~g})$ consisted of wheat flour, rice bran, margarine, milk, eggs, sugar, salt, water and hydrocolloids (HPMC or xanthan, separately). A control dough was prepared without the addition of hydrocolloids. The second dough $(30 \mathrm{~g})$ included only wheat flour and margarine. The two doughs were formed into a round shape and were proved for about 2 hours at $80 \%$ relative humidity. After proving, the second dough was covered by the first dough and formed into $2 \mathrm{~mm}$-thick circular sheets 
with a $140 \mathrm{~mm}$ diameter. Roti doughs were analyzed before and after freezing, as described in section 2.4 to 2.7

\subsection{Freezing and storage conditions}

The surface of each sheet of roti dough was covered with a polyethylene sheet. Then ten pieces of roti dough were stacked vertically on an aluminium tray and frozen in an air-blast freezer at $-18^{\circ} \mathrm{C}$. The temperature of the samples was measured by thermocouples connected to a data logger. Freezing was completed when the core temperature of the roti dough reached $-18^{\circ} \mathrm{C}$. Each lot of ten pieces of roti dough was then packed in a polyethylene bag and stored at $-20^{\circ} \mathrm{C}$ for $0,28,56$ and 84 days. The frozen roti dough sheets were thawed in a microwave oven before being analyzed.

\subsection{Microstructure of the roti dough}

The microstructure of the fresh and frozen roti dough with and without hydrocolloids at different storage times were analyzed using a scanning electron microscope (SEM) with 1000X magnification.

\subsection{Secondary gluten structure}

The secondary structure of the gluten network of the fresh and frozen roti dough with and without hydrocolloids after different storage times was investigated using Fourier transform infrared (FT-IR) spectroscopy. The protocol used in this study was that previously described by Meziani et al. (2011). The amide III band (1200-1350 $\left.\mathrm{cm}^{-1}\right)$ deconvolution produced various peaks and frequencies corresponding to: $\alpha$-helix $\left(1330-1295 \mathrm{~cm}^{-1}\right)$, $\beta$-turn (1295-1270 $\left.\mathrm{cm}^{-1}\right)$, random coil (1270-1250 $\left.\mathrm{cm}^{-1}\right)$ and $\beta$-sheet (1250-1220 $\left.\mathrm{cm}^{-1}\right)$ (Cai \& Singh, 1999).

\subsection{Viscoelastic properties of the roti dough}

The creep and creep recovery of the fresh and frozen roti dough with and without hydrocolloids at different storage times were carried out at a constant stress $(\sigma=100 \mathrm{~Pa})$ for $100 \mathrm{~s}$, then strain $(\gamma)$ recovery for $400 \mathrm{~s}$ after the removal of the stress. The creep data was represented by the creep compliance parameter, $\mathrm{J}(\mathrm{t})$ $\left(\mathrm{Pa}^{-1}\right)=\gamma / \sigma$. The compliance curve data of the roti doughs were analysed based on Burgers model (Dolz et al., 2008) calculated according to the following Equation 1.

$$
J(t)=\frac{1}{G_{0}}+\frac{1}{G_{I}}\left[1-\exp \left(\frac{-t G_{I}}{\eta_{1}}\right)\right]+\frac{t}{\eta_{0}}
$$

where $J(t)\left(\mathrm{Pa}^{-1}\right)$ describes the overall compliance at any time, $\mathrm{G}_{0}$ $(\mathrm{Pa})$ is the instantaneous elastic modulus, $\mathrm{G}_{1}(\mathrm{~Pa})$ is the retarded elastic modulus, $\eta_{0}$ (Pa.s) represents the retarded viscosity and $\eta_{1}$ (Pa.s) is the terminal viscosity.

\subsection{Freezable water}

The freezable water contents of the fresh and frozen roti dough with and without hydrocolloids at different storage times were analyzed using differential scanning calorimetry
(DSC) applying the method described by Leray et al. (2010). The ice melting enthalpy $(\Delta \mathrm{H})$ was obtained by integrating the ice melting peak located at $0{ }^{\circ} \mathrm{C}$ on the thermogram. The percentage of freezable water was calculated by dividing the ice melting enthalpy ( $/ \mathrm{g}$ product) by the latent heat of ice fusion $(\mathrm{L}=333 \mathrm{~J} / \mathrm{g})$ and multiplying by 100 .

\subsection{Statistical analysis}

All the samples were compared using a complete randomize design (CRD). Analysis of variance (ANOVA) was performed and comparisons of means were carried out using Duncan's multiple range test (DMRT) with differences considered to be significant where $\mathrm{p}<0.05$.

\section{Results and discussion}

\subsection{Microstructure of the roti dough}

The microstructure of the roti doughs with and without hydrocolloids was investigated by SEM at a magnification of 1000X (Figure 1). The microstructure of the fresh roti dough without hydrocolloids (Figure 1a) and roti dough with HPMC (Figure 1d) and with xanthan (Figure 1g) showed the continuous matrices of the gluten networks, in which the starch granules were embedded. Both the roti dough with HPMC and that with xanthan had more filaments than the dough without hydrocolloids. This result agrees with previous studies that described fresh dough as a continuous matrix with scattered starch granules (Blaszczak et al., 2004; Chaisawang \& Suphantharika, 2006; Parimala \& Sudha, 2012; Rojas et al., 2000; Smitha et al., 2008).

The microstructure of the frozen roti dough without hydrocolloids was observed to be quite damaged after frozen storage (Figure $1 \mathrm{~b}$ and Figure 1c). The damage increased after frozen storage for 84 days with the gluten strands being more porous, discontinuous and thinner than those of the frozen roti dough after 56 days storage, which could be attributed to the damage to the gluten matrix by ice crystals increasing during storage (Baier-Schenk et al., 2005; Zounis et al., 2002). This result is agreement with that of Yi \& Kerr (2009) who described the dough structure after storage at $-20^{\circ} \mathrm{C}$ for 90 days as being less uniform and with thinner strands. In addition, Ribotta et al. (2005) reported that frozen dough was damaged after 60 days storage at $-18^{\circ} \mathrm{C}$.

In contrast, in the present study, the microstructure of the frozen roti dough with HPMC (Figure 1e) and with xanthan (Figure 1h) did not change during frozen storage of up to 56 days, showing the same structure as that of the gluten matrix of fresh dough. However, increasing the storage time to 84 days resulted in the gluten network of the frozen dough with HPMC showing thinner strands. However, its gluten network was thicker than that of the frozen roti dough without hydrocolloids after storage for 84 days. These results are posited to be due to the hydroxyl groups in the hydrocolloid structure, which permit more water interactions through hydrogen bonding and thus contribute to binding the water in the frozen dough, and thus reduce water migration in the dough during frozen storage (Guarda et al., 2004; Sharadanant \& Khan, 2003; Rosell et al., 2001). 


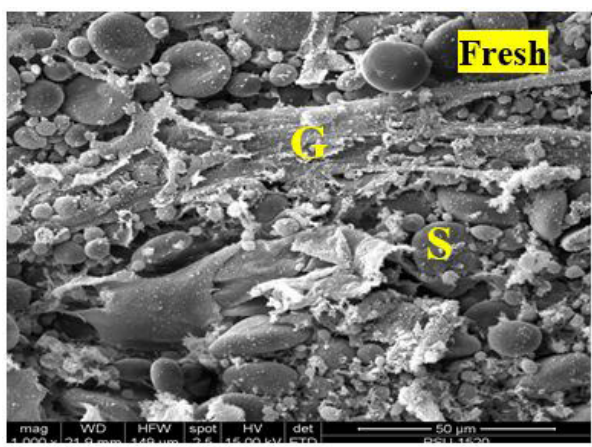

a

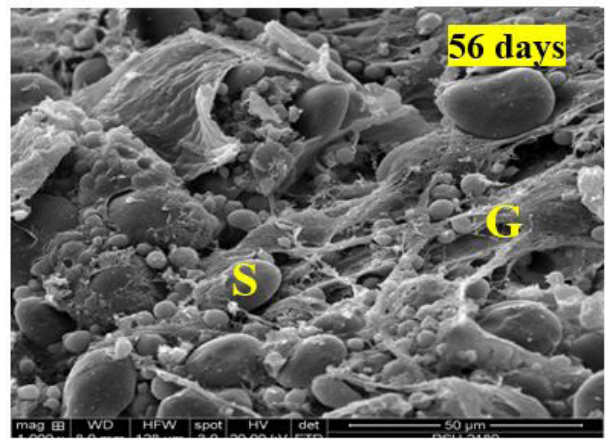

b

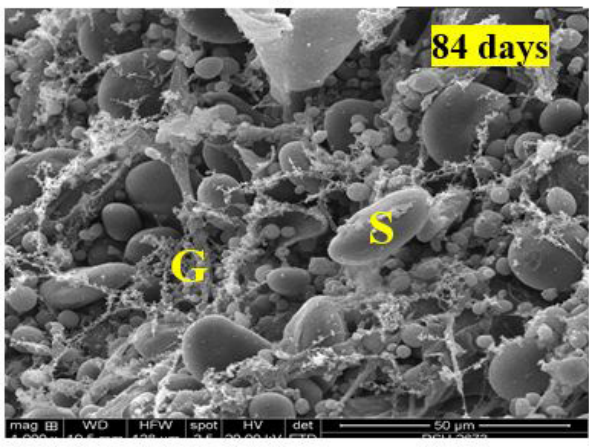

c

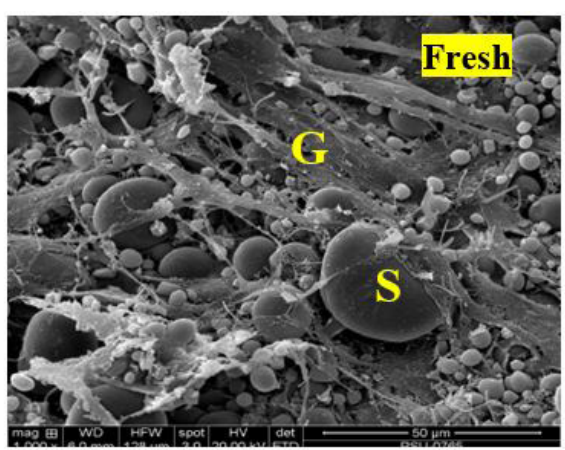

d

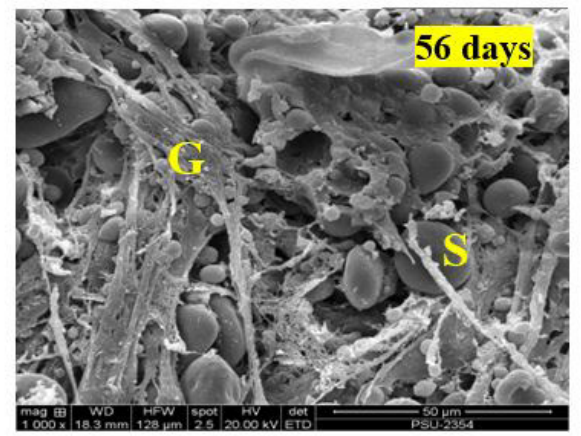

e

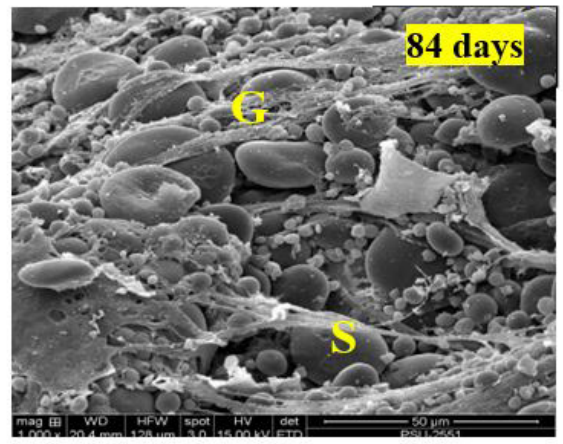

$\mathrm{f}$

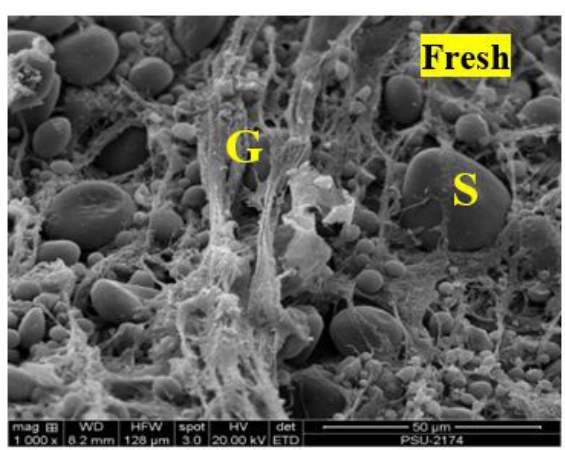

$\mathrm{g}$

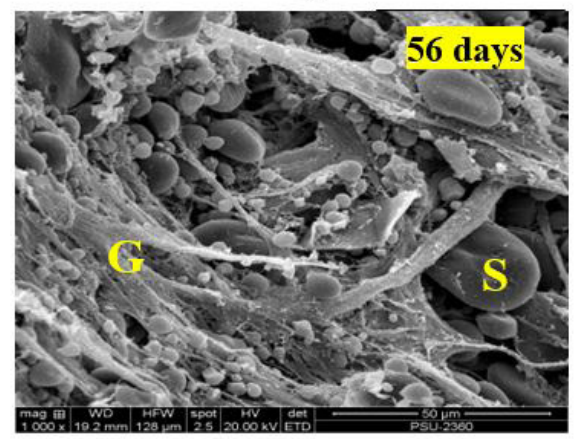

$\mathrm{h}$

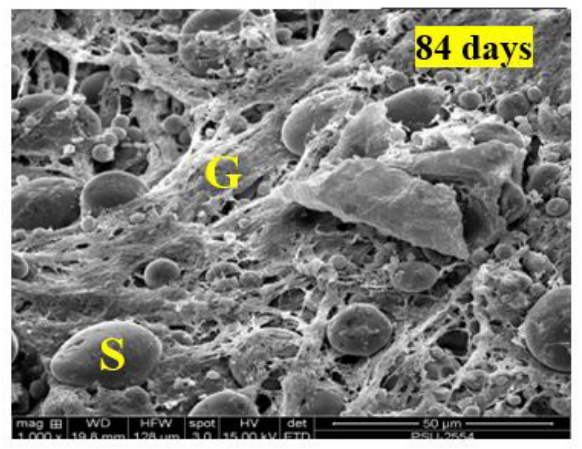

i

Figure 1. Scanning Electron Micrograph (SEM) at 1000X of fresh and frozen roti dough without hydrocolloids (a-c), with 0.75\% HPMC (d-f) and with $0.75 \%$ xanthan (g-i). Roti doughs was frozen and frozen storage at $-18{ }^{\circ} \mathrm{C}$ for 56 and 84 days. G and $\mathrm{S}$ stand for gluten network and starch granule, respectively.

\subsection{Secondary gluten structure}

Figure 2 shows the highest peak at the range of $1250-1220 \mathrm{~cm}^{-1}$ indicating that the secondary structure of the gluten was subject to $\beta$-sheet conformation (Table 1 ). This result agrees with that of Meziani et al. (2011) who reported that gluten proteins mainly contained around $70 \% \beta$-sheet conformation. The $\beta$-sheet and $\beta$-turn conformations in the fresh roti dough with hydrocolloids significantly increased $(\mathrm{p}<0.05)$ while there were decreases in the $\alpha$-helix and random coil conformations compared with the control dough without hydrocolloids (Table 1). This was due to the hydrocolloids consisting of hydrophilic molecules with a high molecular weight, which would be expected to interfere in gluten development, leading to a change in the protein structure (Linlaud et al., 2011). This agrees with the finding of Linlaud et al. (2011) that the addition of xanthan led to a decrease in $\alpha$-helix, indicating a more disordered and labile network, while there was an increased proportion of $\beta$-turn and $\beta$-sheet conformations. In addition, Correa et al. (2014) found a higher contribution of less ordered structures, which was able to accelerate protein interaction. In addition, the results suggested that the roti dough with xanthan had higher $\beta$-sheet confirmation than that of the dough with HPMC, because of the stronger interaction between the anionic functional group (COO-) of xanthan and the cation functional group of the flour proteins. This affects the dough development and results in a higher level of $\beta$-sheet conformation. Moreover, Belton et al. (1995) suggested that $\beta$-sheet conformation is associated with the higher chain mobility created by the increased hydration of glutenin. As protein is hydrated, protein-protein bonds are replaced by protein-water interactions and this permits greater movement of sections in the polypeptide chain, thus forming $\beta$-sheet structures. 
(a)

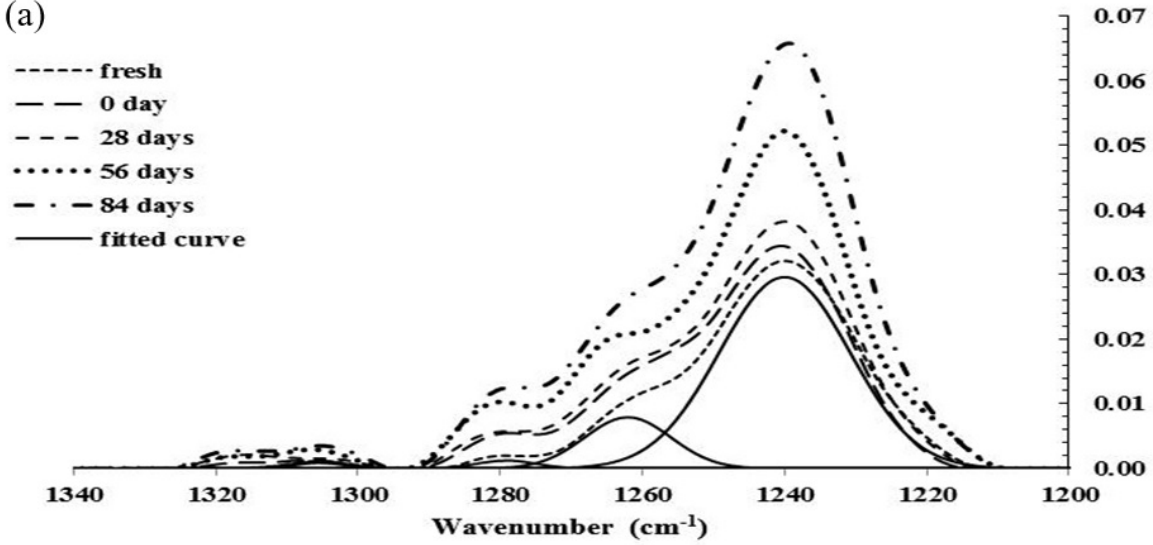

(b)

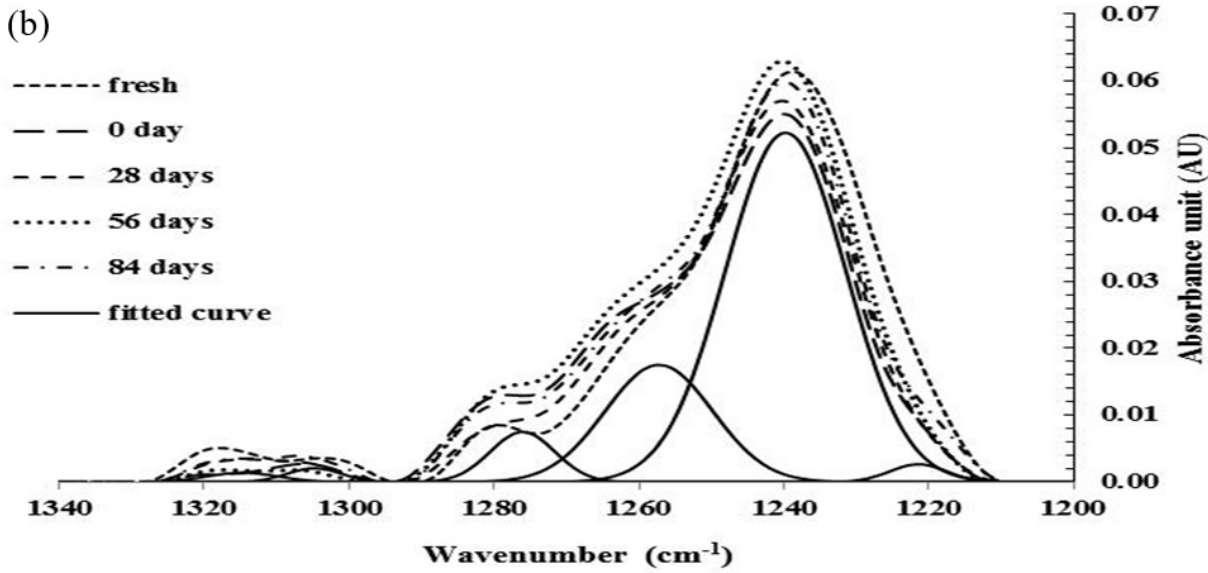

(c)

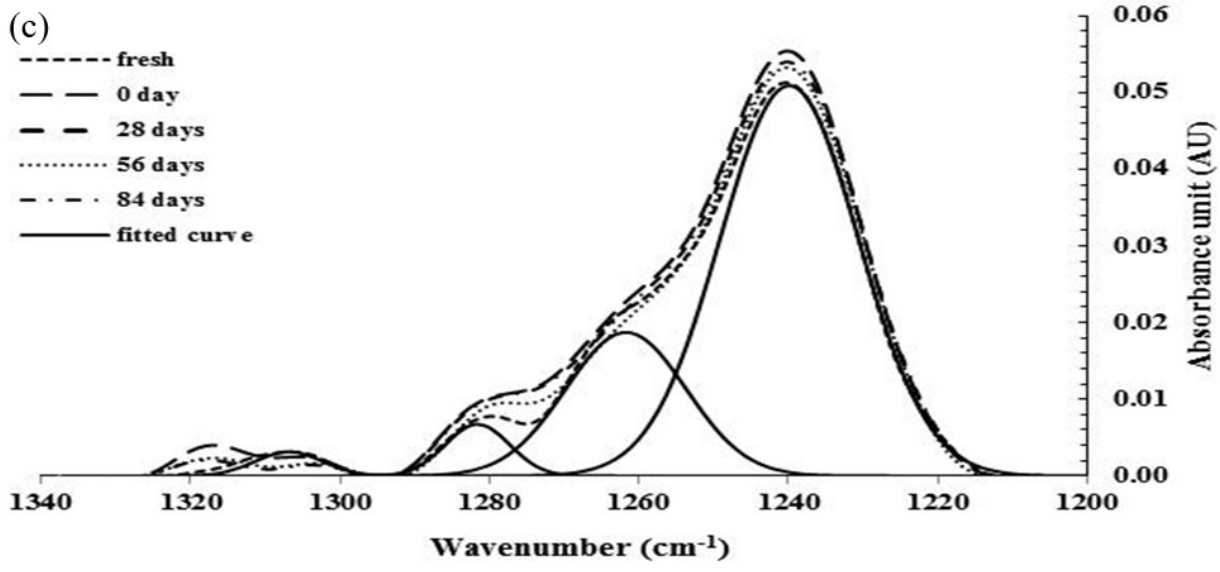

Figure 2. Absorbance Fourier transform infrared spectroscopy (FTIR) spectrum of the $1200-1350 \mathrm{~cm}^{-1}$ region (amide III band) of fresh and frozen roti dough without hydrocolloids (a) with $0.75 \% \mathrm{HPMC}$ (b) and with $0.75 \%$ xanthan (c) during frozen storage time at $-18^{\circ} \mathrm{C}$ for 28,56 and 84 days.

The band intensity of the frozen roti dough without hydrocolloids is shown in Figure 2a. The results showed that the $\beta$-sheet conformation significantly increased $(\mathrm{p}<0.05)$ while the random coil and $\alpha$-helix conformations significantly decreased $(\mathrm{p}<0.05)$ during frozen storage (Table 1). This was probably because during freezing, water diffuses and migrates to form ice crystals which disturb the organized hydrogen bonding system that stabilizes the protein structure. Therefore, hydrophobic and hydrophilic regions of the proteins are exposed to a new environment and new intermolecular cross-links can arise within the protein molecules or between neighboring molecules (Sharadanant \& Khan, 2003). This result agrees with that of Meziani et al. (2011), who described the $\beta$-sheet fraction as being sensitive to freezing and frozen storage with the $\beta$-sheet conformations being increased during the first four weeks of storage. However, the conformational structure of the frozen roti dough with both of the hydrocolloids did not alter during frozen storage (Figure $2 \mathrm{~b}$ and Figure $2 \mathrm{c}$ ). This result is most likely due to the hydrophilic character of the hydrocolloids which alters the degree of water absorption when added to dough (Linlaud et al., 2011), leading to a reduction in the level of freezable water in the dough, and also less changes in the 
Table 1. Conformational changes in the secondary structures of amide III band of fresh and frozen roti dough (FD) with and without hydrocolloids during frozen storage at $-18^{\circ} \mathrm{C}$ or 28,56 and 84 days.

\begin{tabular}{|c|c|c|c|c|}
\hline \multirow{2}{*}{$\begin{array}{c}\text { Treatment/Storage time } \\
\text { (day) }\end{array}$} & \multicolumn{4}{|c|}{ Secondary structure (\%) } \\
\hline & a-helix & $\beta$-turn & random coil & $\beta$-sheet \\
\hline \multicolumn{5}{|l|}{ 1. No hydrocolloids } \\
\hline fresh dough & $4.61 \pm 0.40 \mathrm{c}$ & $3.54 \pm 0.17 \mathrm{abc}$ & $25.60 \pm 0.26 \mathrm{~h}$ & $65.89 \pm 0.50 \mathrm{a}$ \\
\hline FD 28 days & $3.58 \pm 0.55 \mathrm{ab}$ & $3.28 \pm 0.56 \mathrm{a}$ & $21.81 \pm 0.56 \mathrm{efg}$ & $68.21 \pm 0.89 b$ \\
\hline FD 56 days & $3.20 \pm 0.15 \mathrm{a}$ & $3.27 \pm 0.17 \mathrm{a}$ & $19.78 \pm 0.78 b c$ & $71.18 \pm 0.81 \mathrm{~cd}$ \\
\hline fresh dough & $4.53 \pm 0.35 c$ & $3.92 \pm 0.08 \mathrm{cde}$ & $20.56 \pm 0.70 \mathrm{~cd}$ & $72.06 \pm 0.65 \mathrm{cde}$ \\
\hline FD 0 day & $4.47 \pm 0.31 \mathrm{c}$ & $3.87 \pm 0.25 \mathrm{bcde}$ & $20.54 \pm 0.39 c d$ & $71.78 \pm 0.54 \mathrm{cde}$ \\
\hline FD 28 days & $4.45 \pm 0.04 \mathrm{c}$ & $3.79 \pm 0.69 \mathrm{abcd}$ & $21.83 \pm 0.38 \mathrm{efg}$ & $72.50 \pm 0.70 \mathrm{ef}$ \\
\hline FD 56 days & $4.28 \pm 0.30 \mathrm{c}$ & $3.80 \pm 0.45 \mathrm{abcd}$ & $21.07 \pm 0.56 \mathrm{de}$ & $72.15 \pm 0.54 \mathrm{de}$ \\
\hline FD 84 days & $4.38 \pm 0.07 c$ & $4.12 \pm 0.10 \mathrm{cde}$ & $21.49 \pm 0.63 \mathrm{def}$ & $70.99 \pm 0.73 c$ \\
\hline FD 56 days & $3.26 \pm 0.06 \mathrm{a}$ & $4.39 \pm 0.14 \mathrm{de}$ & $19.95 \pm 0.45 \mathrm{~g}$ & $74.83 \pm 0.15 h$ \\
\hline FD 84 days & $3.24 \pm 0.24 \mathrm{a}$ & $4.27 \pm 0.32 \mathrm{de}$ & $19.57 \pm 0.57 \mathrm{defg}$ & $73.95 \pm 0.66 \mathrm{gh}$ \\
\hline
\end{tabular}

Each value is mean of triplicate \pm SD. The different superscript letter under the same column are significantly different $(\mathrm{p}<0.05)$.

gluten matrix due to formation of ice crystals during freezing and frozen storage. In addition, The frozen roti dough with xanthan was found to experience less changes in the random coil conformation during frozen storage than that in the frozen roti dough with HPMC, probably because of the stronger interaction between this hydrocolloid and the flour proteins (Rosell et al., 2001; Mandala et al., 2008).

\subsection{Viscoelastic properties}

The creep compliance curve of the roti dough with and without hydrocolloids exhibited a typical combination of elastic and viscous components (Figure 3), which was able to be fitted to a 4-element Burgers model. This curve was similar to that derived in previous studies of wheat dough (Lazaridou et al., 2007; Rouille et al., 2005; Wang \& Sun, 2002). The fresh roti dough with hydrocolloids had lower instantaneous elastic modulus $\left(G_{0}\right)$, retarded elastic modulus $\left(G_{1}\right)$, retarded viscosity $\left(\eta_{1}\right)$ and terminal viscosity $\left(\eta_{N}\right)$ than those of the fresh dough without hydrocolloids as showed in Table 2. This result agrees with that of Rosell \& Foegeding (2007) who found decreased storage modulus $\left(G^{\prime}\right)$ with the addition of hydrocolloids to bread. The decrease in $G_{0}$ and $G_{1}$ indicates a decrease in elastic properties and the lower $\eta_{1}$ and $\eta_{\mathrm{N}}$ indicate a lower resistance to flow (Mandala, 2005). The fresh roti dough with xanthan had higher $G_{0}$ and $G_{1}$ than the roti dough with HPMC and this agrees with the results of previous studies, that $G^{\prime}$, which indicates the strength of the dough, decreased with the addition of HPMC (Cai \& Singh, 1999; Lorenzo et al., 2009; Mandala, 2005; Rosell et al., 2001). Further, Lorenzo et al. (2009) found that dough formulated with xanthan and guar gum had the highest $G^{\prime}$ values, while the lowest values were found in HPMC dough. This effect has been attributed to the hydroxyl groups in the HPMC structure which allow more water interactions through hydrogen bonding (Rosell et al., 2001).

The $\mathrm{G}_{0}$ and $\mathrm{G}_{1}$ of the frozen roti dough without hydrocolloids (Table 2) significantly decreased $(\mathrm{p}<0.05)$ during frozen storage, which indicates a decrease in the elastic properties and lower recoverability of the dough due to ice crystal formation during frozen storage. This agrees with previous studies, which found that the $\mathrm{G}^{\prime}$ of dough decreased during frozen storage (Angioloni et al., 2008; Ribotta et al., 2004) and in this study, the $\mathrm{G}^{\prime}$ of the roti dough with both HPMC and xanthan did not change during 84 days frozen storage due to the strong interaction between the hydrocolloids and protein previously mentioned.

\subsection{Freezable water}

The amount of freezable water in the fresh and frozen roti dough was investigated by DSC as shown in Table 3 . The $\Delta \mathrm{H}$ value, calculated as the area under the peak of the freezing endotherm and representing the energy change that occurred during the melting of ice in the frozen dough, was taken as an indicator of the amount of freezable water present in the dough. The $\Delta \mathrm{H}$, and thus, the freezable water in the fresh dough without hydrocolloids was higher than that of the roti dough with hydrocolloids. This result agrees with that of Sharadanant \& Khan (2003), who found that the addition of different hydrocolloids to dough caused significantly decreased $(p<0.05)$ freezable water, probably due to the hydroxyl groups in the hydrocolloid structure allowing more water interaction (Guarda et al., 2004; Rosell et al., 2001), leading to more water absorption. In this study, the roti dough with HPMC had a lower $\Delta \mathrm{H}$ and thus, freezable water than that of the roti dough with xanthan. This is probably due to the substitution of the hydroxyl groups of the cellulose by the hydroxyl, methoxyl and hydroxypropyl group of 
(a)

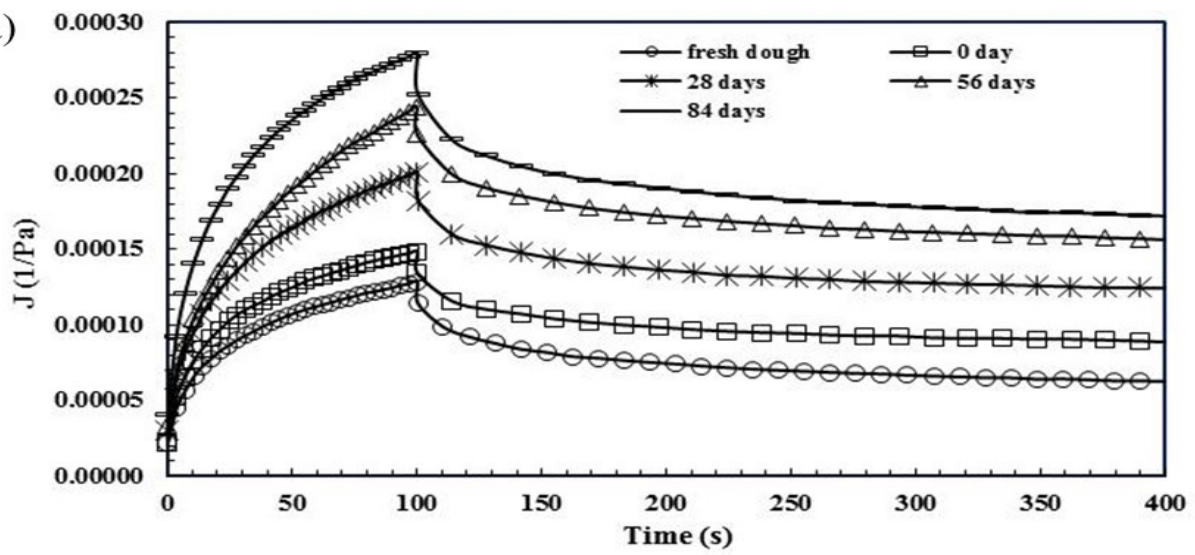

(b)

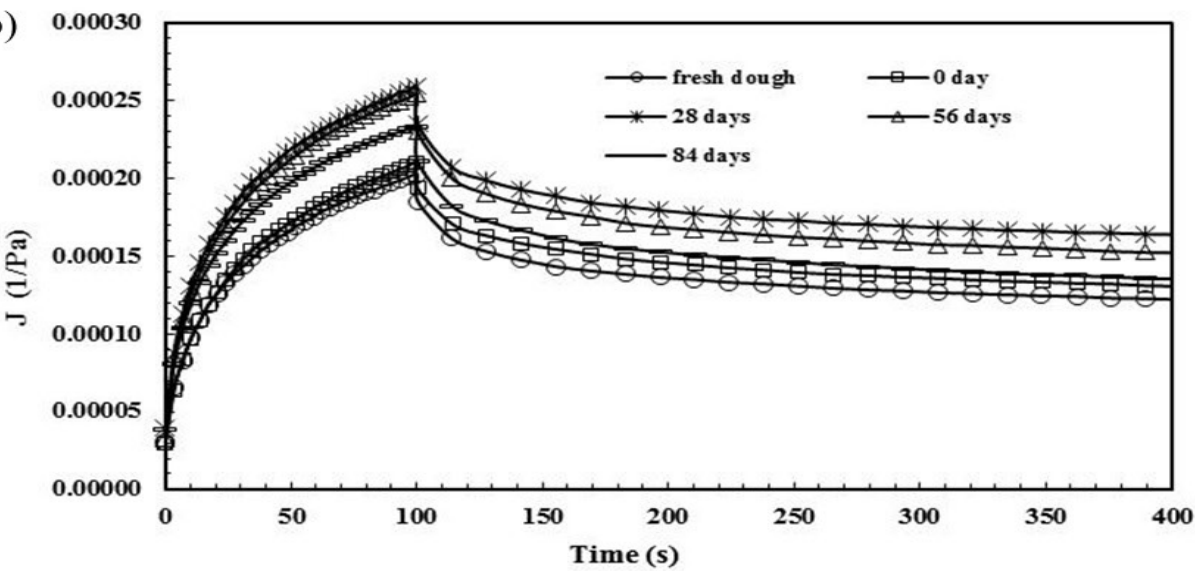

(c)

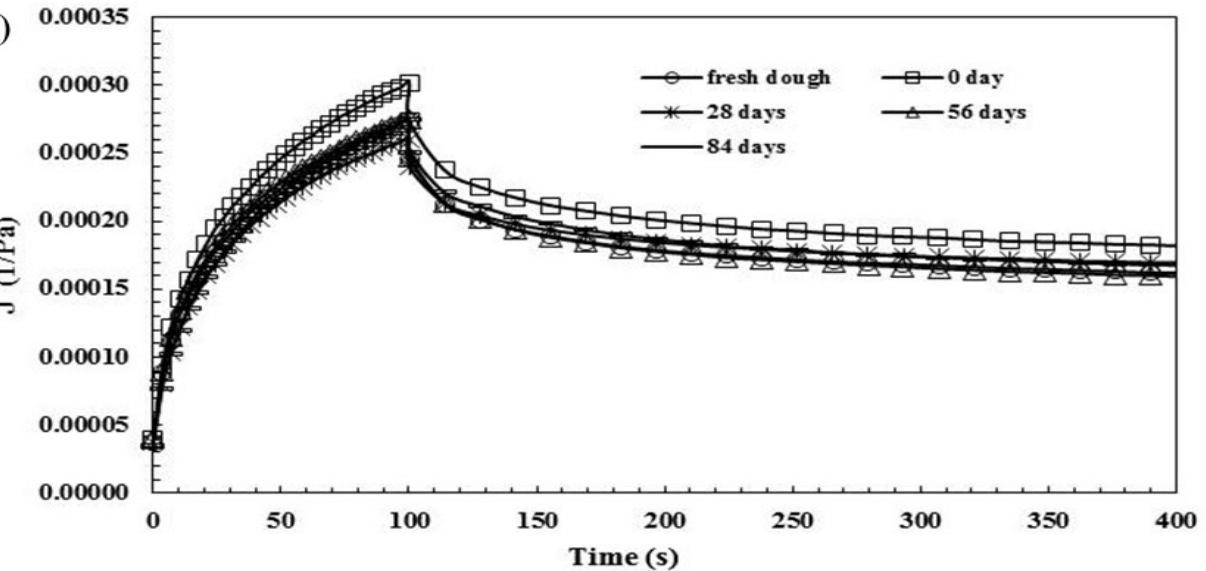

Figure 3. Creep compliance and creep recovery of fresh and frozen roti dough without hydrocolloids (a), 0.75\% HPMC (b) and 0.75\% xanthan (c) during frozen storage at $-18^{\circ} \mathrm{C}$ for 28,56 and 84 days. All samples were measured at $25^{\circ} \mathrm{C}$ and strain at $100 \mathrm{~Pa}$.

the HMPC which increased the water absorption in the HPMCsupplemented dough (Barcenas et al., 2004). Sharadanant \& Khan (2003) reported that decreasing freezable water led to reduced ice crystals in the dough, consequently improving the frozen dough quality.

The frozen roti dough without hydrocolloids showed a significantly increased $\Delta \mathrm{H}(\mathrm{p}<0.05)$ with longer frozen storage time. The freezable water in the frozen roti dough without hydrocolloids increased from 42.79 to $74.11 \%$ with increased frozen storage time from 0 to 84 days, the difference being significant at $\mathrm{p}<0.05$, and this result agrees with those of previous studies (Sharadanant, \& Khan, 2003; Matuda et al., 2008). Increasing freezable water causes deterioration in the gluten network as a result of ice crystals forming during freezing, with recrystallization of the ice crystals during frozen storage inducing the separation of water from the other components of the dough (Sharadanant \& Khan, 2003). The $\Delta \mathrm{H}$ and freezable water of the frozen roti dough with HPMC and xanthan both 
Original Article

Muadiad; Sirivongpisal

Table 2. Creep parameter of fresh and frozen roti dough (FD) with and without hydrocolloids during frozen storage at $-18^{\circ} \mathrm{C}$ for 28,56 and 84 days.

\begin{tabular}{|c|c|c|c|c|c|}
\hline \multirow{2}{*}{ Storage time (days) } & \multirow{2}{*}{$\begin{array}{l}\text { Ideal elastic } \\
\mathrm{G}_{0}(\mathrm{~Pa}) \times 10^{4}\end{array}$} & \multicolumn{3}{|c|}{ Viscoelastic } & \multirow{2}{*}{$\frac{\text { Viscosity }}{\eta_{\mathrm{N}}(\mathrm{Pa} . \mathrm{s}) \times 10^{6}}$} \\
\hline & & $\mathrm{G}_{1}(\mathrm{~Pa}) \times 10^{4}$ & $\eta_{1}($ Pa.s $) \times 10^{5}$ & $\tau_{1}(\mathrm{Sec})$ & \\
\hline \multicolumn{6}{|l|}{ 1. No hydrocolloids } \\
\hline Fresh dough & $4.68 \pm 0.09 c$ & $1.50 \pm 0.04 \mathrm{e}$ & $3.65 \pm 0.30 \mathrm{e}$ & $23.82 \pm 0.57 \mathrm{e}$ & $3.16 \pm 0.18 \mathrm{~d}$ \\
\hline FD 0 day & $4.27 \pm 0.77 \mathrm{c}$ & $1.39 \pm 0.15 \mathrm{e}$ & $3.26 \pm 0.42 \mathrm{e}$ & $23.33 \pm 0.26 \mathrm{de}$ & $3.26 \pm 0.20 \mathrm{~d}$ \\
\hline FD 28 days & $3.13 \pm 0.02 b$ & $0.82 \pm 0.07 \mathrm{bcd}$ & $1.91 \pm 0.14 \mathrm{cde}$ & $23.17 \pm 0.28 \mathrm{de}$ & $2.62 \pm 0.25 b c$ \\
\hline FD 56 days & $2.85 \pm 0.22 b$ & $0.74 \pm 0.16 \mathrm{bd}$ & $1.60 \pm 0.26 \mathrm{bcd}$ & $21.76 \pm 1.10 \mathrm{abc}$ & $2.26 \pm 0.30 \mathrm{~b}$ \\
\hline FD 84 days & $2.30 \pm 0.15 \mathrm{a}$ & $0.50 \pm 0.09 a$ & $1.10 \pm 0.15 \mathrm{a}$ & $20.94 \pm 0.74 \mathrm{a}$ & $1.75 \pm 0.27 \mathrm{a}$ \\
\hline \multicolumn{6}{|l|}{ 2. HPMC } \\
\hline Fresh dough & $2.92 \pm 0.28 \mathrm{~b}$ & $0.88 \pm 0.14 \mathrm{~cd}$ & $1.97 \pm 0.30 \mathrm{de}$ & $22.39 \pm 0.45 b c d$ & $2.46 \pm 0.13 b c$ \\
\hline FD 0 day & $2.80 \pm 0.18 \mathrm{ab}$ & $0.81 \pm 0.10 \mathrm{bc}$ & $1.80 \pm 0.30 \mathrm{bcd}$ & $22.19 \pm 0.83 \mathrm{bcd}$ & $2.39 \pm 0.18 b c$ \\
\hline FD 28 days & $2.74 \pm 0.20 \mathrm{ab}$ & $0.72 \pm 0.04 \mathrm{bc}$ & $1.60 \pm 0.13 \mathrm{bcd}$ & $22.16 \pm 0.72 \mathrm{abcd}$ & $2.32 \pm 0.24 b c$ \\
\hline FD 56 days & $2.77 \pm 0.12 \mathrm{ab}$ & $0.64 \pm 0.08 \mathrm{~b}$ & $1.44 \pm 0.16 b$ & $21.71 \pm 0.14 \mathrm{abc}$ & $2.22 \pm 0.14 b$ \\
\hline FD 84 days & $2.82 \pm 0.22 \mathrm{~b}$ & $0.69 \pm 0.04 \mathrm{~b}$ & $1.49 \pm 0.08 b c$ & $21.62 \pm 0.87 \mathrm{abc}$ & $2.28 \pm 0.03 b c$ \\
\hline \multicolumn{6}{|l|}{ 3. Xanthan } \\
\hline Fresh dough & $3.13 \pm 0.23 b$ & $0.99 \pm 0.13 \mathrm{~d}$ & $2.25 \pm 0.26 \mathrm{e}$ & $22.73 \pm 0.34 \mathrm{cde}$ & $2.80 \pm 0.55 \mathrm{~cd}$ \\
\hline FD 0 day & $3.12 \pm 0.29 b$ & $0.77 \pm 0.13 b c$ & $1.71 \pm 0.31 \mathrm{bcd}$ & $22.34 \pm 0.43 \mathrm{bcd}$ & $2.54 \pm 0.31 b c$ \\
\hline FD 28 days & $2.92 \pm 0.30 \mathrm{~b}$ & $0.70 \pm 0.03 b c$ & $1.85 \pm 0.29 \mathrm{bcde}$ & $21.41 \pm 0.87 \mathrm{ab}$ & $2.55 \pm 0.31 b c$ \\
\hline FD 56 days & $2.79 \pm 0.04 \mathrm{ab}$ & $0.67 \pm 0.06 b$ & $1.48 \pm 0.10 \mathrm{bc}$ & $22.23 \pm 0.43 \mathrm{bcd}$ & $2.37 \pm 0.36 b c$ \\
\hline FD 84 days & $3.01 \pm 0.08 \mathrm{~b}$ & $0.70 \pm 0.66 b$ & $1.58 \pm 0.16 \mathrm{bcd}$ & $22.67 \pm 0.70 \mathrm{bcde}$ & $2.52 \pm 0.21 b c$ \\
\hline
\end{tabular}

Each value is mean of triplicate \pm SD. The different superscript letters under the same column are significantly different $(\mathrm{p}<0.05)$.

Table 3. Enthalpy of ice melting $(\Delta \mathrm{H})$ and freezable water of fresh and frozen roti dough with air blast freezing during frozen storage at $-18^{\circ} \mathrm{C}$.

\begin{tabular}{lcc}
\hline \multicolumn{1}{c}{ Storage time (days) } & Enthalpy $(\Delta \mathrm{H}, \mathrm{J} / \mathrm{g})$ & $\begin{array}{c}\text { Freezable water } \\
(\% \text { of total water })\end{array}$ \\
\hline $\begin{array}{l}\text { 1. No hydrocolloids } \\
\text { fresh dough }\end{array}$ & $43.22 \pm 0.61^{\mathrm{d}}$ & $37.67 \pm 0.53^{\mathrm{c}}$ \\
FD 0 days & $48.29 \pm 0.63^{\mathrm{f}}$ & $42.79 \pm 0.56^{\mathrm{f}}$ \\
FD 28 days & $51.69 \pm 0.42^{\mathrm{gh}}$ & $45.80 \pm 0.37^{\mathrm{h}}$ \\
FD 84 days & $83.64 \pm 0.87^{\mathrm{i}}$ & $74.11 \pm 0.77^{\mathrm{j}}$ \\
2. HPMC & & \\
fresh dough & $36.67 \pm 0.59^{\mathrm{a}}$ & $33.13 \pm 0.53^{\mathrm{a}}$ \\
FD 0 days & $38.21 \pm 0.77^{\mathrm{b}}$ & $34.52 \pm 0.70^{\mathrm{b}}$ \\
FD 28 days & $43.81 \pm 0.35^{\mathrm{d}}$ & $39.58 \pm 0.32^{\mathrm{d}}$ \\
FD 84 days & $52.44 \pm 0.42^{\mathrm{h}}$ & $47.37 \pm 0.38^{\mathrm{i}}$ \\
3. Xanthan & & \\
fresh dough & $41.73 \pm 0.87^{\mathrm{c}}$ & $36.98 \pm 0.77^{\mathrm{c}}$ \\
FD 0 days & $44.07 \pm 0.68^{\mathrm{d}}$ & $39.05 \pm 0.61^{\mathrm{d}}$ \\
FD 28 days & $47.10 \pm 0.30^{\mathrm{e}}$ & $41.73 \pm 0.26^{\mathrm{e}}$ \\
FD 84 days & $51.28 \pm 0.83^{\mathrm{g}}$ & $44.70 \pm 0.72^{\mathrm{g}}$ \\
\hline Each value is mean of triplicate $\pm \mathrm{SD}$. The different superscript letters under the same \\
column are significantly different $(\mathrm{p}<0.05)$. &
\end{tabular}

significantly increased $(\mathrm{p}<0.05)$ with increasing frozen storage from 0 to 84 days. However, the freezable water in the frozen roti dough with hydrocolloids showed less change than that experienced by the roti dough without hydrocolloids. This result could be due to the strong interaction between the hydrocolloids and protein previously mentioned. Moreover, the freezable water in the frozen roti dough with HPMC showed a greater increase than that in the xanthan-supplemented dough during frozen storage. This probably due to the greater ability of xanthan to bind freezable water and thus, reduce ice crystal formation, which was also evident from the decrease resistance-to-extension values.

\section{Conclusion}

Increasing the storage time of frozen roti dough supplemented with rice bran leads to a decrease in its quality by changing the protein structure ( $\beta$-sheet and random coil) and increasing the freezable water content. Furthermore, a decreased resistance to extension and instantaneous elastic modulus but increased extensibility indicates a decrease in the elastic properties of the frozen roti dough as well as lower recoverability after storage. However, the quality of the frozen roti dough was improved by adding $0.75 \%$ of the hydrocolloids HPMC or xanthan, with the best improvement in overall quality being produced by the addition of xanthan. The frozen roti dough made with these hydrocolloids had a stable structure and rheological properties after frozen storage.

\section{Acknowledgements}

The authors would like to express their sincere thanks to Prince of Songkla University for supporting the Government Budget fund (AGR540066M).

\section{References}

Angioloni, A., Balestra, F., Pinnavaia, G. G., \& Rosa, M. D. (2008). Small and large deformation tests for the evaluation of frozen dough viscoelastic behavior. Journal of Food Engineering, 87(4), 527-531. http://dx.doi.org/10.1016/j.jfoodeng.2008.01.007.

Baier-Schenk, A., Handschin, S., Von Schonau, M., Bittermann, A. G., Bachi, T., \& Condepetit, B. (2005). In situ observation of the freezing process in wheat dough by confocal laser scanning microscopy (CLSM): formation of ice and changes in the gluten network. Cereal Science, 42(2), 255-260. http://dx.doi.org/10.1016/j.jcs.2005.04.006. 
Barcenas, M. E., Benedito, C., \& Rosell, C. M. (2004). Use of hydrocolloids as bread improvers in interrupted baking process with frozen storage. Food Hydrocolloids, 18(5), 769-774. http://dx.doi.org/10.1016/j. foodhyd.2003.12.003.

Belton, P. S., Colquhoun, I. J., Grant, A., Wellner, N., Field, J. M., Shewry, P. R., \& Tatham, A. S. (1995). FTIR and NMR studies on the hydration of a high-MR subunit of glutenin. Journal of Biological Macromolecules, 17(2), 74-80. http://dx.doi.org/10.1016/01418130(95)93520-8. PMid:7547718.

Blaszczak, W., Sadowska, J., Rosell, C. M., \& Fornal, J. (2004). Structural changes in the wheat dough and bread with the addition of alphaamylases. Journal European Food Research and Technology, 219(4), 348-354. http://dx.doi.org/10.1007/s00217-004-0972-8.

Cai, S., \& Singh, B. R. (1999). Identification of b-turn and random coil amide III infrared bands for secondary structure estimation of proteins. Biophysical Chemistry, 80(1), 7-20. http://dx.doi.org/10.1016/ S0301-4622(99)00060-5. PMid:10457593.

Chaisawang, M., \& Suphantharika, M. (2006). Pasting and rheological properties of native and anionic tapioca starches as modified by guar gum and xanthan gum. Food Hydrocolloids, 20(5), 641-649. http:// dx.doi.org/10.1016/j.foodhyd.2005.06.003.

Correa, M. J., Anon, M. C., Perez, G. T., \& Ferrero, C. (2014). Effect of modified celluloses on dough rheology and microstructure. Food Research International, 43(3), 780-787. http://dx.doi.org/10.1016/j. foodres.2009.11.016.

Dolz, M., Hernandez, M. J., \& Delegido, J. (2008). Creep and recovery experimental investigation of low oil content food emulsions. Food Hydrocolloids, 22(3), 421-427. http://dx.doi.org/10.1016/j. foodhyd.2006.12.011.

Guarda, A., Rosell, C. M., Benedito, C., \& Galotto, M. J. (2004). Different hydrocolloids as bread improvers and antistaling agents. Food Hydrocolloids, 18(2), 241-247. http://dx.doi.org/10.1016/ S0268-005X(03)00080-8.

Lazaridou, A., Duta, D., Papageorgiou, P., Belc, N., \& Biliaderis, C. G. (2007). Effects of hydrocolloids on dough rheology and bread quality parameters in gluten-free formulations. Journal of Food Engineering, 79(3), 1033-1047. http://dx.doi.org/10.1016/j. jfoodeng.2006.03.032.

Leray, G., Oliete, B., Mezaize, S., Chevallier, S., \& Lamballerie, M. (2010). Effects of freezing and frozen storage conditions on the rheological properties of different formulations of non-yeasted wheat and gluten-free bread dough. Journal of Food Engineering, 100(1), 70-76. http://dx.doi.org/10.1016/j.jfoodeng.2010.03.029.

Linlaud, N., Ferrer, E., Puppo, M. C., \& Ferrero, C. (2011). Hydrocolloid interaction with water, protein, and starch in wheat dough. Journal of Agricultural and Food Chemistry, 59(2), 713-719. http://dx.doi. org/10.1021/jf1026197. PMid:21175189.

Lorenzo, L., Zaritzky, N. E., \& Califano, A. N. (2009). Rheological characterization of refrigerated and frozen non-fermented glutenfree dough: effect of hydrocolloids and lipid phase. Journal of Cereal Science, 50(2), 255-261. http://dx.doi.org/10.1016/j.jcs.2009.06.003.

Mandala, I. G. (2005). Physical properties of fresh and frozen stored, microwave-reheated breads, containing hydrocolloids. Journal of Food Engineering, 66(3), 291-300. http://dx.doi.org/10.1016/j. jfoodeng.2004.03.020.

Mandala, I. G., \& Sotirakoglou, K. (2005). Effect of frozen storage and microwave reheating on some physical attributes of fresh bread containing hydrocolloids. Food Hydrocolloids, 19(4), 709-719. http:// dx.doi.org/10.1016/j.foodhyd.2004.09.001.
Mandala, I., Karabela, D., \& Kostaropoulos, A. (2008). Physical properties of breads containing hydrocolloids stored at low temperature. I. Effect of chilling. Food Hydrocolloids, 21(8), 1397-1406. http:// dx.doi.org/10.1016/j.foodhyd.2006.11.007.

Matuda, T. G., Chevallier, S., Pessôa, P. A. Fo., LeBail, A., \& Tadini, C. C. (2008). Impact of guar and xanthan gums on proofing and calorimetric parameters of frozen bread dough. Journal of Cereal Science, 48(3), 741-746. http://dx.doi.org/10.1016/j.jcs.2008.04.006.

Meziani, S., Jasniewski, J., Gaiani, C., Ioannou, I., Muller, J. M., Ghoul, M., \& Desobry, S. (2011). Effects of freezing treatments on viscoelastic and structural behavior of frozen sweet dough. Journal of Food Engineering, 107(3-4), 358-365. http://dx.doi.org/10.1016/j.jfoodeng.2011.07.003.

Parimala, K. R., \& Sudha, M. L. (2012). Effect of hydrocolloids on the rheological, microscopic, mass transfer characteristics during frying and quality characteristics of puri. Food Hydrocolloids, 27(1), 191200. http://dx.doi.org/10.1016/j.foodhyd.2011.07.005.

Ribotta, P. D., Ausar, S. F., Beltramo, D. M., \& Leon, A. E. (2005). Interactions of hydrocolloids and sonicated-gluten proteins. Food Hydrocolloids, 19(1), 93-99. http://dx.doi.org/10.1016/j. foodhyd.2004.04.018.

Ribotta, P. D., Pérez, G. T., León, A. E., \& Añón, M. C. (2004). Effect of emulsifier and guar gum on microstructural, rheological and baking performance of frozen bread dough. Food Hydrocolloids, 18(2), 305-315. http://dx.doi.org/10.1016/S0268-005X(03)00086-9.

Rojas, J. A., Rosell, C. M., Benedito de Barber, C., Perez-Munuera, I., \& Lluch, M. A. (2000). The baking process of wheat rolls followed by cryo scanning electron microscopy. European Food Research and Technology, 212(1), 57-63. http://dx.doi.org/10.1007/s002170000209.

Rosell, C. M., \& Foegeding, A. (2007). Interaction of hydroxypropylmethylcellulose with gluten proteins: Small deformation properties during thermal treatment. Food Hydrocolloids, 21(7), 1092-1100. http://dx.doi.org/10.1016/j.foodhyd.2006.08.003.

Rosell, C. M., Rojas, J. A., \& Benedito de Barber, C. (2001). Influence of hydrocolloids on dough rheology and bread quality. Food Hydrocolloids, 15(1), 75-81. http://dx.doi.org/10.1016/S0268-005X(00)00054-0.

Rouille, J., Della Valle, G., Lefebvre, J., Sliwinski, E., \& Van Vliet, T. (2005). Shear and extensional properties of bread doughs affected by their minor components. Journal of Cereal Science, 42(1), 45-57. http://dx.doi.org/10.1016/j.jcs.2004.12.008.

Sharadanant, R., \& Khan, K. (2003). Effect of hydrophilic gums on frozen dough. I. Dough quality. Cereal Chemistry, 80(6), 764-772. http://dx.doi.org/10.1094/CCHEM.2003.80.6.764.

Smitha, S., Rajiv, J., Begum, K., \& Indrani, D. (2008). Effect of hydrocolloids on rheological, microstructural and quality characteristics of parottaan unleavened flat bread. Journal of Texture Studies, 39(3), 267-283. http://dx.doi.org/10.1111/j.1745-4603.2008.00142.x.

Wang, F. C., \& Sun, X. S. (2002). Creep-recovery of wheat flour doughs and relationship to other physical dough tests and breadmaking performance. Cereal Chemistry, 79(4), 567-571. http://dx.doi. org/10.1094/CCHEM.2002.79.4.567.

Yi, J., \& Kerr, W. L. (2009). Combined effects of freezing rate, storage temperature and time on bread dough and baking properties. Food Science and Technology, 42(9), 1474-1483. http://dx.doi.org/10.1016/j. lwt.2009.05.017.

Zounis, S., Quail, K. J., Wootton, M., \& Dickson, M. R. (2002). Effect of final dough temperature on the microstructure of frozen bread dough. Journal of Cereal Science, 36(2), 135-146. http://dx.doi. org/10.1006/jcrs.2001.0407. 